\title{
How do Alberta's, Ontario's and Quebec's forest operation laws respect ecological sustainable forest management criteria in the boreal forest?
}

\author{
by Laurence Bourgeois ${ }^{1}$, Daniel Kneeshaw² ${ }^{2}$ Louis Imbeau ${ }^{3}$ Nicolas Bélanger ${ }^{4}$, Stephen Yamasaki ${ }^{5}$ and Suzanne Brais ${ }^{6}$
}

\begin{abstract}
In order to receive forest certification and to respond to societal desires, many forest companies are attempting to demonstrate that their forest activities are «sustainable». The main objective of this paper is to qualitatively evaluate the ways in which forestry-related provincial regulations in the three provinces (Alberta, Ontario and Quebec) that contain most of the Canadian boreal forest help forest companies achieve certification with respect to ecological criteria. In the process of continually evolving towards sustainable forest management, we evaluate how these provincial regulations governing forest operations can be helpful in maintaining three criteria: biodiversity, the aquatic environment and soils. This study shows that the regulations evaluated have varied in their approach and thus have different strengths that must be underlined: (1) Ontario's approach is the strongest in terms of biodiversity, (2) Alberta and Ontario provide measures to abandon roads after harvesting, (3) Quebec provides the greatest specific measures for protecting waterways and aquatic species, (4) Alberta shows the greatest consideration for maintaining the most soil properties and functions. Better links between different regulations are necessary in all jurisdictions. The continual improvement of Canadian forest rules is often slow and advances at a different pace depending on regulators but it should be supported in all provinces.
\end{abstract}

Key words: sustainable forest management, biodiversity, aquatic environment, soils, Alberta, Ontario, Quebec

\section{RÉSUMÉ}

Afin d'obtenir une certification forestière et de répondre aux besoins de la société, les compagnies doivent démontrer que leurs activités forestières sont «durables». L'objectif principal de cet article est d'évaluer de quelles façons les normes forestières provinciales des ministères des ressources naturelles aident les compagnies forestières à obtenir une certification environnementale. Nous avons évalué de façon qualitative les lois encadrant les opérations forestières en forêt boréale, la zone forestière dominante au Canada. Nous mettons l'emphase sur trois provinces (Alberta, Ontario et Québec) qui couvrent la plus grande proportion de la zone boréale au pays. Dans une démarche d'amélioration continue, nous évaluons comment ces normes peuvent aider à maintenir trois critères : la biodiversité, le milieu aquatique et les sols. Cette étude montre que ces règlements présentent des différences dans leurs approches et des forces qui doivent être soulignées: (1) l'approche de l'Ontario est la plus forte en termes de biodiversité, (2) l'Alberta et l'Ontario proposent des mesures pour abandonner les routes suite aux activités de récolte, (3) le Québec offre les meilleures mesures spécifiques pour un nombre de milieux humides et d'espèces aquatiques, (4) l'Alberta présente la meilleure réflexion sur le maintien du plus grand nombre de propriétés et fonctions des sols. De meilleurs liens entre les différentes lois sont nécessaires bien qu'il faille appuyer l'amélioration continue des règlements forestiers au Canada.

Mots-clés : aménagement forestier durable, biodiversité, milieu aquatique, sols, Alberta, Ontario, Québec

\footnotetext{
${ }^{1}$ Groupe de recherche en écologie forestière interuniversitaire (GREFi), Département des sciences biologiques, Université du Québec à Montréal, C.P. 8888, succursale Centre-Ville, Montréal, Québec H3C 3P8. E-mail: laurencebourgeois@hotmail.com, bourgeois.laurence@ courrier.uqam.ca

${ }^{2}$ Corresponding author; GREFi, Département des sciences biologiques, Université du Québec à Montréal, C.P. 8888, succursale CentreVille, Montréal, Québec H3C 3P8. E-mail: kneeshaw.daniel@uqam.ca

${ }^{3}$ Chaire industrielle CRSNG-UQAT-UQAM en aménagement forestier durable, Université du Québec en Abitibi-Témiscamingue, Département des sciences appliquées, 445 boul. de l’Université, Rouyn-Noranda, Québec J9X 5E4. E-mail: Louis.Imbeau@uqat.ca ${ }^{4}$ Department of Soil Science, University of Saskatchewan, 51 Campus Drive, Saskatoon, Saskatchewan S7N 5A8. E-mail: nicolas.belanger@ usask.ca

${ }^{5}$ Institut québécois d’Aménagement de la Forêt feuillue, 58, rue Principale, Ripon, Québec, J0V 1V0. E-mail: syamasaki@iqaff.qc.ca ${ }^{6}$ Chaire industrielle CRSNG-UQAT-UQAM en aménagement forestier durable, Université du Québec en Abitibi-Témiscamingue, Département des sciences appliquées, 445 boul. de l’Université, Rouyn-Noranda, Québec, J9X 5E4. E-mail: Suzanne.Brais@uqat.ca
} 


\section{Introduction}

In order to respond to pressure from the public, environmentalists and global timber markets, the majority of Canadian forestry companies have chosen forest certification (Forest Stewardship Council (FSC), Canadian Standards Association (CSA), Sustainable Forest Initiative (SFI)) as a means of demonstrating that their forestry operations are "sustainable." Despite different approaches, all certification programs require that enterprises respect the laws of the jurisdiction in which they operate. In many instances, provincial laws and rules can also help in the achievement of forest certification. Despite improvement in scientific knowledge and in forestry practices that have occurred over past decades, there are still shortcomings in our understanding of forest ecosystem processes and response to forest management that must be addressed. Thus, there is a need to evaluate the degree to which existing rules help companies to achieve environmental certification, and to continually improve Sustainable Forest Management (SFM). The following can therefore serve as an approach to be used in other forest types and jurisdictions.

As a first step, we identified scientific concepts that should be considered in order to ensure the maintenance of ecological criteria related to biodiversity, the aquatic environment and soils (Fig. 1). Our decision to evaluate a subset of SFM criteria (biodiversity, aquatic environment and soils) identified by the Canadian Council of Forestry Ministers (CCFM) (2003) is based on the fact that forest companies already have expertise with the other SFM criteria. In terms of ecological indicators, forest companies have a good knowledge of forest productivity, and are therefore able to evaluate the productivity indicators targeted by certification organisations. Furthermore, as ecologists we have chosen to focus particularly on ecological criteria. SFM requires the maintenance of societal needs, and these may at times lead to a trade-off with ecological factors. Although such an evaluation should be undertaken, it is beyond the scope of this paper. Global cycles will also not be evaluated. Despite the existence of local contributions to these cycles, the subject is probably better treated on a scale larger than that of a Forest Management Unit (FMU).

We evaluate regulations governing forestry operations in the boreal forest, the dominant forest zone in Canada. We focus on the three provinces (Alberta, Ontario and Quebec) that cover the largest proportion of the boreal forest. The regulations evaluated are the Timber Harvest Planning and Operating Ground Rules in Alberta, the Forest Operations and Silviculture Manual in Ontario and the RNI (Règlement sur les Normes d'Intervention or Rules for operating standards) ${ }^{7}$ in Quebec. Although other provinces have a great dependency on the forest sector; much of their wood comes from nonboreal forests. Our qualitative evaluation, based on the expertise of the authors, is presented in terms of requirements that have been satisfied, practices that require improvements and strategies that could be favoured to achieve SFM goals for each criterion (Table 1) (see also Kneeshaw and Bourgeois 2003). Finally, a list of research priorities is identified for each of the three criteria that are evaluated.

\section{Choice and justification of the reference manuals for Alberta,} Ontario and Quebec

In each of the three jurisdictions being studied, we identified with local experts a series of regulations governing forest management operations. In some instances these may not be the only regulations governing all facets of forest management operations; it is crucial to make clear that our analysis, except where otherwise detailed, is restricted to these primary series of regulations.

\section{Alberta}

We evaluated the Timber Harvest Planning and Operating Ground Rules (hereafter called "the Ground Rules"; Section 5 of the Forests Act and Section 100 (b) of the Timber Management Regulation), which provide direction to timber operators as well as to the government for planning, implementing and monitoring timber operations on timber licence and permit areas in Alberta (Alberta Environmental Protection 1994). This document highlights important management principles, defines operating and planning objectives, and presents standards and guidelines for timber harvest, road development, reclamation, reforestation and integration of timber harvesting with other forest uses.

\section{Ontario}

Forest management in Ontario is regulated by the Crown Forest Sustainability Act (CFSA), for which four manuals exist that outline the rules and procedures for forest management on Crown lands in Ontario. As the goal of this article is to investigate how provincial regulations affect forestry operations, we evaluated only the rules and guidelines set out in the Forest Operations and Silviculture Manual ${ }^{8}$ (OMNR 1995). Although other regulations affecting forestry operations may be found in the other manuals, they are beyond the scope of the current study.

\section{Quebec}

In Quebec, the Ministry of Natural Resources and Wildlife (MRNF) has developed a set of rules governing forest management activities referred to as the RNI (Règles sur les normes d'intervention, Rules on standards of intervention) (MRN $2000 \mathrm{~b}, 2002 \mathrm{a})$. In our evaluation, we used the RNI regulations in effect as of November 26, 2002 (MRN 2002b). This set of rules is one of the key tools governing forest management operations in Quebec and complements other and rules developed by the MRNF (e.g., the Manuel d'aménagement and the $\mathrm{PGAF}^{9}$ ) and other ministries.

\section{Evaluation of the Three Criteria \\ Biodiversity}

Guiding concept: a double filter approach

To achieve SFM, we cannot isolate natural environments to protect them from anthropogenic disturbances; instead we must "filter" interventions in order to maintain biodiversity. Conservation biologists have proposed two approaches: the coarse filter (a global approach for the protection of habitat, 


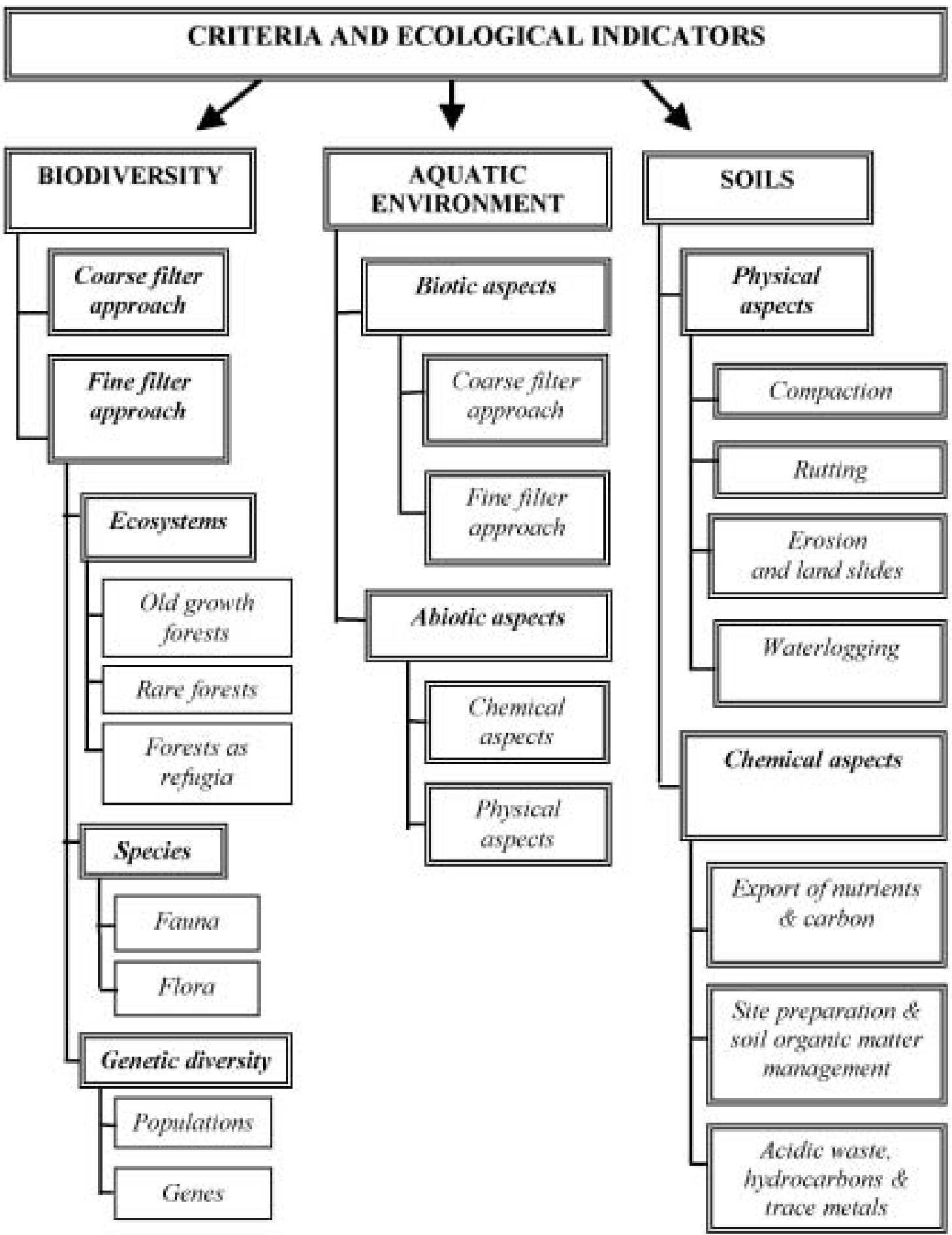

Fig. 1. Flowchart of ecological criteria and key indicators for maintaining biodiversity, the aquatic environment and soils (Kneeshaw et al. २0०३). 
Table 1. Synthesis of satisfied requirements, challenges and strategies to be favoured to maintain biodiversity, aquatic environment and soils in Alberta $(A)$, Ontario $(0)$ and Quebec $(Q)$ (Kneeshaw et al. 2003).

Biodiversity

Satisfied requirements

Challenges and strategies to be favoured

Wildlife habitat and biodiversity

A: recognition of the importance of the planning phase in ensuring the maintenance of wildlife habitat

O: recognition that landscape level management at the coarse

filter scale is necessary for maintaining biodiversity.

Herbicide and pesticide

Q: the only jurisdiction to ban herbicide and pesticide use.

Specific species

O: some rules (that could be considered fine filter measures) protect specific species (especially game species) but are addressed at highly visible species instead of those in greatest need of protection.

O: fall under the Federal Law governing endangered and threatened species.

Mature-overmature or old growth habitat

AO: some provisions for consideration of mature-overmature or old growth habitat. (For Ontario, see Old growth policy for Ontario's crown forests and Old growth forest definitions for Ontario).

\section{Access to forestry roads}

AO: measures governing the destruction of access to some forestry roads to limit easy access.

Leaving snags on site

O: the guide for natural disturbance pattern treats by variable retention.

Genetic diversity

Links with other laws and guides
Q: greater consideration of biodiversity objectives in the planning phase.

Q: respect of coarse filter approach by developing a strategy to promote recovery of recently disturbed habitats.

AQ: should consider evaluating the link between the fine filter approach and the coarse filter approach as success of the dual-filter strategy to ensure the preservation of the largest number of species. AQ: necessity for greater consideration of the habitat needs of threatened species to preserve viable populations over the long term.

Q: legislation to protect old-growth habitat is currently lacking although some measures are under discussion and likely to be implemented in the next year or two.

AQ: Respect coarse filter approach by developing a strategy for the maintenance of old-growth forest.

Q: provisions to limit access to some forest areas need to be developed.

AQ: needs to be better supported by regulations. The effects of salvage logging should be assessed and suitable measures provided to control this activity.

AQ: respect coarse filter approach by increasing retention of structural elements in harvested areas and developing a better strategy for dispersal of harvest blocks in time and space.

AOQ: should better develop effective strategies based on seed zones and provenances to maintain genetic diversity. A coarse filter approach that supports meta-populations will provide some measures to maintain genetic diversity.

AOQ: linkages should be made clear. A separate document could be used to show these links if they cannot be inserted directly into existing regulations.

Aquatic Environment

Satisfied requirements

Running waters

AOQ: many measures protect running waters, especially from road crossings

Chemical quality of water

AOQ: many measures have indirect but positive effects on the protection of the chemical quality of water
Challenges and strategies to be favoured

Q: need to consider watercourse size.

Q: The Quebec-Cree-agreement offers interesting guidelines that identify particular rivers as more than $5 \mathrm{~m}$ wide (Art. 3.12.2) or large lakes having a surface area of more than $5 \mathrm{~km}^{2}$.

A: identifies watercourse size.

AOQ: direct measures need to be developed.

AOQ: should better invest in approaches based on watersheds; respecting effects on chemical factors see AOP and PGAF. 
Table 1. Synthesis of satisfied requirements, challenges and strategies to be favoured to maintain biodiversity, aquatic environment and soils in Alberta (A), Ontario (O) and Quebec (Q) (Kneeshaw et al. 2003) (continued).

Aquatic Environment

Satisfied requirements

Challenges and strategies to be favoured

Aquatic biodiversity

O: some measures to protect aquatic life, primarily fish, by protecting their passage in streams as well as aspects of fish habitat

AQ: improvements are still needed. Comparison of the effects of forestry cuts and natural disturbances permits evaluation of variations for a given type of ecosystem. Integration of biodiversity aspects should be undertaken.

Watershed

Duration of effects of forest management

AOQ: needs more consideration.

AOQ: should limit cuts in a watershed to a proportion of the forested area.

AOQ: needs more consideration.

AOQ: better understanding and thus more study is required on the duration of the effects of forest management on the aquatic environment.

Soils

Satisfied requirements

Challenges and strategies to be favoured

Erosion

AOQ: some legislation exists to minimise the effects of erosion, especially respecting activities linked to road construction.

Landslides

A: The effects of land use activities on landslides are primarily a preoccupation in hillslope areas such as the foothills and Rockies.

Compaction of soils

Q: some measures treat soil compaction in wet environments.

AOQ: improvements are still required because the treatment is often indirect and thus potentially incomplete.

AOQ: should provide better links between regulations and the guides of good practice that protect the various elements mentioned in this table as slopes, wetlands, shallow soils.

Rutting

Waterlogging

Q: some conditions are considered in articles 16 and 89 of the RNI

Preservation of carbon

Q: some measures treat carbon preservation.

Preservation of the nutrient capital of sites

Q: some measures are aimed at preserving the nutrient capital of sites. The contamination of soils is treated indirectly by the Law on the quality of the environment.

AOQ: there are no measures concerning rutting, just a follow-up. Improvements are still required.

AOQ: measures have to be improved and be directly aimed at evaluating changes in soil carbon.

AOQ: the greatest challenge is in ensuring the preservation of the nutrient capital of sites. Some measures to preserve soil fertility on poor sites should be developed. Site degradation and compaction should be better considered.

AOQ: simulation models (e.g., SAFE, Forecyte, Forecast, Century) could also help evaluate the effect of different harvesting scenarios on different types of soils.

Distribution of skid trails in a harvest block

AOQ: must therefore constitute compromise between the area of a disturbance and its severity.

AOQ: the methods to assess and remedy potential problems

Soil productivity

A: some measures directly treat soil productivity. 
the preservation of ecological processes and, thus, the diversity of an entire forested landscape) and the fine filter (a combination of more specific measures applied to conserve species or populations whose survival is not ensured following the application of the coarse filter (Hunter et al. 1988).

The coarse filter approach suggests that we could maintain a large proportion of species (including those that might not appear to be threatened) and genes by ensuring the preservation of ecosystems and processes controlling forest dynamics (Franklin 1993). For forest managers, this equals a combination of protected areas and ecosystem management of the matrix. A management strategy seeking to ensure the maintenance of old-growth forest habitat and coarse woody debris would thus (conserve areas large enough to permit some forests to attain the old-growth stage despite the occurrence of large-scale disturbances (fires and insect outbreaks) and plan to provide for key elements structuring this habitat outside protected areas.

The fine filter approach is theoretically designed to be complementary to the coarse filter. The ecosystems, species and genes to be protected using this approach are those that pass through the coarse filter and that require special, supplementary protection or a more refined approach to ensure their survival. Threatened and endangered species require that their specific needs be known in order to be protected through specific measures. A strategy that aims at the preservation of one type of ecosystem or some static examples of ecosystems would be considered as a fine filter strategy. An example is the protection of small areas of old-growth forest under the Exceptional Forest Ecosystems (EFE) program of the Quebec MRNF.

In order to apply the best possible double filter through management strategies, it is necessary to consider three levels of biodiversity: ecosystem diversity, species diversity and diversity within each species (genetic diversity) (Fig. 1).

\section{Satisfied requirements}

All provinces are moving towards greater consideration of biodiversity objectives in forest management planning. In some cases (i.e., Quebec and Alberta) this will eventually result in the coarse filter approach being considered outside of the currently evaluated guidelines and regulations. One important advantage to addressing biodiversity in the planning phase is that regional differences in habitat can be considered, making it easier to move away from the blanket approach often inherent in prescriptive province-wide regulations. Such an approach will also be more flexible and will hopefully result in foresters responding more quickly to new scientific knowledge.

Ontario's regulations recognize that landscape level management at the coarse filter scale is needed in order to maintain biodiversity. It also recognises that a one-size fits all approach using general prescriptive rules for the entire province is not ideal for maintaining biodiversity. In this sense, it is ahead of the two other provinces being compared. However, such recognition is recent and success is therefore difficult to evaluate. In Quebec, the regulatory approach found in the RNI is not conducive to the flexibility required for an effective coarse filter strategy. New directives in Quebec would enable forest managers greater flexibility in managing for biodiversity at multiple scales in long-term forest management plans.
In terms of habitat needs of late-successional species and minimizing fragmentation effects, Alberta and Ontario both have provisions for retaining overmature or old-growth habitats. There are also considerations for minimizing the effects of roads on biodiversity in Alberta and Ontario, for example by rendering unusable many tertiary roads following harvesting. This will reduce human access and subsequent deleterious effects on biodiversity (i.e., through hunting, poaching, vehicle traffic, fragmentation, cottage development, other land use, etc). Indeed, roads have no natural analogue and provide access to territories that have previously been relatively inaccessible to most of the human population (Bourgeois et al. 2006). An increase in road networks is currently still favoured in Quebec. This policy aims to promote public use of the forest and thus may be a point for CCFM Criterion 5 (benefits to society), although it has potential negative effects on biodiversity.

Among other differences, it is noteworthy that Quebec is the only jurisdiction that has banned herbicide and pesticide use. The long-term effects of such a strategy on biodiversity remain to be evaluated, although this could be considered a plus for smaller organisms and micro-organisms as well as for public acceptance.

At the fine filter scale, there is a great recognition in Alberta of the importance of the planning phase in ensuring the maintenance of key wildlife habitats, i.e., those that may not be addressed by the coarse filter approach.

Ontario's approach is the strongest in terms of considering and managing its forests for biodiversity. It offers the greatest flexibility and consideration for maintaining species and their habitats, through an effective integration of measures at both coarse and fine filter scales. Habitat management guidelines are provided not only for economically important game species, but also for those in the greatest need of intervention, such as forest raptors (OMNR 1984a), cavity-nesting birds (OMNR 1984b), and even bats (OMNR 1984c). The RNI in Quebec have not been developed with this goal and although the regulations may be useful to protect some well-known species, forest managers in Quebec should attempt to maintain biodiversity more broadly within the PGAF. Alberta can probably be considered intermediate between Quebec and Ontario in its approach.

\section{Challenges}

Scientific evidence exists to show that naturally disturbed areas containing abundant quantities of dead trees can be important habitat for several species of invertebrates, mammals and birds (Hannah and Hoyt 2004, Nappi et al. 2004). Consequently, coarse filter plans in all provinces should consider the long-term provision of naturally disturbed habitats. The effect of salvage logging on biodiversity needs be assessed and suitable measures provided to control this activity. Currently, the lack of consideration of the effects of salvage logging must be addressed. Indeed, such policies should be formulated before major natural disturbances occur, rather than being designed as special emergency plans, such as those being implemented in Quebec. These policies may have detrimental effects by removing large quantities of "biological legacy" essential for taxa, which are poorly adapted to the interactive effects of these two disturbances in rapid succession (fire followed by logging) (Lindenmayer et al. 2004). 
Currently, regulations exist in the evaluated provinces to prohibit or limit the quantity of usable wood fibre left behind on a site despite increasing experimentation with tree-retention practices in harvest blocks. It is hoped that the modifications to the measures to avoid wasteful practices will facilitate techniques to specifically leave behind standing trees in Ontario. Such modifications have not yet been adopted in Quebec or in Alberta, where legislation also exists to control leaving usable wood fibre behind in cut blocks. Such regulations are clearly in opposition to strategies that attempt to preserve minimal levels of key elements essential for species relying on standing dead wood. In this case, provincial regulations may even contradict the guiding principles behind some forest certification schemes.

All provinces should evaluate the link between the fine filter approach and the coarse filter approach. Such a link is crucial to the success of the dual-filter strategy. Currently, however, most of the species-specific measures we found address the situation of highly visible species rather than those that have passed through the coarse filter and which are in the greatest need of protection. For example, Quebec has a number of regulations to protect specific wildlife species. However, these species (such as moose) are usually of socioeconomic interest and not those needing specific protection measures. In other words, few of the species mentioned in Quebec's RNI have passed through the coarse filter and are in need of fine filter protection.

Genetic diversity will at least partially be maintained by a coarse filter approach that helps to maintain meta-populations. Rules and guidelines that are being developed or that have been developed based on seed zones and provenances may be a useful tool in the development of a strategy for the conservation of genetic diversity. Nevertheless, across the country very little information is available to develop effective strategies to maintain genetic diversity.

\section{Strategies to be favoured}

The double filter approach suggests that several elements should be added (to varying degrees) to the current rules governing forestry operations in all jurisdictions: (1) the maintenance of all ecosystems and successional levels, especially in the case of old-growth forests and recently disturbed habitats, (2) retention of structural elements in cut areas combined with a better dispersal of cuts as inspired by natural disturbance patterns, and (3) a better consideration of the effects of a permanent and widespread road network.

The use of alternative harvesting systems that leave behind standing wood (either as groups of live trees or as individuals) needs to be better supported by regulations in order to maintain suitable foraging and nesting sites for primary excavators and other cavity-nesting birds (Imbeau and Desrochers 2002) as well as to provide a continuous supply of snags in various deterioration categories used by several invertebrates, mammals, amphibians, and birds (McComb and Lindenmayer 1999, Similä et al. 2003).

\section{Aquatic environment}

Guiding concepts: maintenance of abiotic and biotic factors within natural variability

The impact of forestry operations on water quality is one of the major preoccupations of government organizations regulating forestry. Since potential effects are multiple, we have divided them into two categories-abiotic and biotic. The first category focuses on effects on both the physical environment (e.g., preservation of stream beds, protection against sedimentation) and the chemical quality of water (e.g., DOC, nutrients, heavy metals), whereas the second deals with forestry effects on aquatic biodiversity (e.g., fish, amphibians, primary producers) using the double filter approach.

\section{Satisfied requirements}

In general, management objectives (general as well as specific) and targeted rules offer a good starting point for protecting the abiotic aspects of water. In all provinces, many of the measures designed to protect the aquatic environment from physical disturbances to river beds and shorelines will also have positive effects on the protection of water chemistry. However, it should be noted that significant changes in water chemical quality can occur without apparent physical disturbance. These effects are either not considered or only poorly or superficially addressed.

From a biotic perspective, there are some measures to protect aquatic life, primarily fish, by protecting fish-ways in streams and other aspects of fish habitat. Ontario's approach is the strongest in terms of aquatic biodiversity. Alberta and Ontario provide measures to close roads after harvesting. The thrust in Ontario again seems to be more towards the biotic component, although measures are provided to minimize sedimentation. Quebec provides the most specific measures for protecting watercourses and aquatic species. Quebec also provides specific measures for a number of wetland and aquatic species. It should be noted that almost half of the measures in the RNI (MRN 2002b) address the protection of elements of the aquatic environment.

\section{Challenges}

The term "aquatic environment" is currently too vague. It would be preferable to have more specific objectives depending on the type of watercourse or aquatic environment under evaluation. Precision regarding type and size of watercourse could be important, since the effects of harvesting are probably different for first order and fifth order streams as well as for lakes. Alberta provides some potential for exploring this by specifying watercourse size, while the Quebec-Cree Agreement offers some guidelines such as for rivers more than $5 \mathrm{~m}$ wide and for lakes larger than $5 \mathrm{~km}^{2}$. A current problem in Quebec is that watercourse definitions differ between ministries; thus defining objectives related to watercourse parameters will probably require much time and effort. The simplest solution in the short term (and that used in Quebec's $R N I$ ) is to produce a guide to facilitate interpretation of terminology.

In the same way, a greater effort should be invested in approaches to manage forests by watershed, especially respecting management effects on water chemistry. Watersheds are addressed to some extent in large-scale and long-term planning exercises such as PGAFs in Quebec and Operating Plans in Alberta.

Finally, one of the areas that requires more understanding in all provinces and thus more study is the duration of disturbance effects on aquatic environments (Plamondon 1993). This is as true for the duration of effects following natural disturbance as it is for timber harvesting operations.

Regarding the protection of aquatic biodiversity, improve- 
ments are still required. Our knowledge of requirements for many groups of organisms is limited and more directed study is required in order to ensure an effective use of the fine filter.

\section{Strategies to be favoured}

The usefulness of specific measures applied indiscriminately over large areas should be reviewed (e.g., should residual bands $20 \mathrm{~m}$ wide be left bordering all waterways with no consideration of topography or size of the water body or watercourse?). A better understanding of the duration is also needed. For example, a disturbance whose effects are mitigated in four or five years will be less important than another of the same magnitude whose effects are permanent. The duration of effects is also likely to depend on the type of ecosystem considered. For example, a big lake with a long hydraulic residence time could be affected for a longer time period (but perhaps less intensely) than a small stream. The notion of sustainability is difficult to integrate into the regulated context of the RNI and the Ground Rules (although the required input from specialists may help) and may be more easily addressed by an approach by objectives (Ministère du Conseil Exécutif du Québec 2001). Again, it should be stressed that sets of regulations (other than those studied) governing planning practices at larger scales may be useful in achieving objectives (Alberta Environmental Protection 1994, Ontario Ministry of Natural Resources 1995).

Spatial and temporal comparison of the effects of forest harvesting on the aquatic environment with the effects of natural disturbances offers an interesting approach through examining natural variations in a given type of ecosystem (Kneeshaw et al. 2000a, b). Alternative strategies to manage the entire forest so as to minimize impacts on water exist. For example, Carignan et al. (2000) in central Quebec suggested limiting harvested areas as a proportion of the total forested area in a watershed. However, the applicability of this approach to other regions still needs to be evaluated (i.e., claybelt regions where watersheds are extremely large and where local effects need to be considered).

Aquatic ecosystems are complex systems and can be affected in many ways, by direct effects as well as by indirect ones. An integration of physical, chemical and biodiversity aspects should thus be undertaken.

\section{Soils}

Many activities can affect the physical matrix of the soil. The most important impacts of forest management are erosion, compaction, rutting, and landslides as well as waterlogging. Apart from altering soil physical structure, forestry operations influence nutrient cycling and storage and cycling of carbon reserves. Furthermore, small amounts of heavy metals, acidic wastes, oils and petroleum hydrocarbons, and other contaminants are released by machinery during normal forestry operations.

Changes in soil structure and in carbon and nutrient cycles have a large influence on conservation of the soil resource as well as on the biota that depend on soil. Thus, there is a need to consider the physical impacts of forestry operations on the soil matrix. In terms of the chemical aspects, we focus on the impacts on nutrient cycles, carbon reserves and soil contamination.

\section{Satisfied requirements}

All three provinces provide legislation to minimize soil erosion. This is especially true with respect to activities linked to road construction. Direct effects of forestry operations (harvesting and site preparation) on erosion also need to be evaluated. The effects of land use activities on landslides are primarily a preoccupation in steep hillslope areas such as the Foothills and the Rockies (it is therefore considered in Alberta). Some measures exist in the different provinces to reduce compaction and protect soil structure (e.g., Brais 2001), although the degree to which they are enforced needs to be assessed. The treatment of soil compaction appears to be variable among provinces (e.g., only Quebec provides measures to deal with soil compaction in poorly drained environments and wetlands). Although rutting is a concern in some areas, it is not always dealt with in provincial regulations, but in some cases it is addressed in accompanying guides (e.g., L'Écuyer and Jetté 1998). Modifications to water table levels should be more directly and explicitly treated. Measures also exist to protect or remediate sites in special cases (i.e., sand or gravel pits). Some provinces (Quebec) have measures that favour the preservation of soil carbon, although they are not directly developed with the goal of evaluating changes in the carbon cycle.

\section{Challenges}

Greater consideration needs to be given to the potential effect of forestry operations on soil contamination. Currently, this is at least indirectly addressed through laws such as Quebec's Quality of the Environment Act (Ministère de l'Environnement du Québec 2002).

Perhaps the greatest challenge is in ensuring preservation of the nutrient capital of sites. Changes in forest management operations in the 1960s (e.g., whole-tree harvesting) and increased tree growth due to improved silviculture and use of fast-growing tree species may favour increased nutrient exports from the ecosystem until they could become limiting. Increased air pollution, including an increase in precipitation acidity and soil leaching, will exacerbate the export of base cations (a problem for acidic soils). Methods of assessing and remedying potential problems require much refinement. The scale of these losses depends on the composition and the age of the stands as well as the productivity of the soil (i.e., problems will be greatest on poor sites) and the type of harvesting carried out (by stem or by whole tree). Although it should be easy to quantify nutrient losses, the consequences for longterm productivity are more difficult to predict. We note, however, that a tool exists for boreal forests (Paré et al. 2002) and allows a first approximation (i.e., to identify the most sensitive sites) for potential nutrient problems following different types of harvesting. More research should be focused on this subject (for example, how will successive and accelerated forest rotations affect long-term productivity?).

Finally, there is a strong need to better understand and consider the temporal aspects of the physical degradation of a site. On clay soils, for example, the largest effect of compaction is in the first two passages, but compaction can increase with the number of passages on coarse textured soils. Forest regulations should consider to a greater extent the effects of harvesting on mesic soils. It is known that as soil 
compacts, the probability that ruts are produced increases. Soils that are not frozen and that have high a moisture content are always susceptible to rutting no matter what the texture of the soil (Brais and Camiré 1998).

\section{Strategies to be favoured}

Better links between regulations and the guides to practice on thin soils, on steep slopes and in wetlands (or other wet environment types) should be developed (e.g., Ontario's Code of Practice for Timber Management Operations in Riparian Areas) (OMNR 1998). Recently, tools and guides have been developed that suggest which soils are most at risk from nutrient depletion. These guides consider the dynamic nature of cycles and forestry revolutions (MRNQ 1997, 2001; Jetté et al. 1998; Schreiber et al. 1999; Molloy et al. 2001). Simulation models (e.g., SAFE, Forecyte, Forecast, Century) could also help in evaluating the effect of different scenarios on nutrient dynamics in different types of soils.

From the point of view of protecting soil quality, it may be preferable to distribute skidder paths across the entire harvest block. However, the trade-off is that such a practice may destroy too much of the advance regeneration. Links with other indicators must therefore be apparent, with clear priorities (Kneeshaw et al. 2000a). On fine-textured soils, compaction is harmful, and concentrating machinery traffic on regularly spaced paths is justified. However, concentration of such an activity must not create serious rutting.

\section{Future Research Needs}

Kneeshaw et al. (2000a) note that SFM is a continual process of improvement and that two types of indicators are necessary in order to achieve this goal, i.e., planning and monitoring indicators. Planning indicators help orient operations towards interventions that are believed to be "sustainable," while monitoring indicators serve to evaluate the extent to which objectives have been achieved. These two groups of indicators function together in a feedback system and thereby facilitate continuous improvement. It should also be noted that indicators may change with the development of new knowledge, which will lead to adaptive management. In the following section, we propose a number of research orientations that we consider necessary in order to approach SFM.

\section{Biodiversity}

A better understanding of all natural processes is a key for developing effective ecosystem management strategies. Despite some knowledge on the response of wildlife to forestry operations, our understanding is often limited to only a few studies focusing on relatively small areas over short time periods. The scientific literature suggests that many effects may not become apparent for many years or even generations (Tilman et al. 1994, Hanski 2000). This same literature shows that responses may not be linear, but that thresholds may exist beyond which populations decline rapidly, thus putting the long-term survival of species in peril. It is therefore crucial that long-term studies be reproduced in different ecosystems in order to increase confidence in our knowledge and predictive abilities. Simulation modelling will be complementary to these empirical studies.

It is also important to determine the importance and role of different habitats (e.g., old-growth forests) and the thresh- olds above which their reduction would cause negative effects. Research on conservation areas (effects of their configuration, their size, as well as their placement in the landscape and their abundance) is necessary for an effective planning strategy for the maintenance of biodiversity and its required habitat. The effectiveness of variable retention strategies and partial cuts to maintain key elements of old forests should also be documented. In this vein, more research is needed on habitat requirements at different temporal and spatial scales for species in peril.

We should also improve our understanding of aspects affecting genetic diversity. In-situ and ex-situ conservation as well as managing for meta-populations have not yet been sufficiently studied. However, Joyce et al. (2001) have designed a framework for identifying species / populations "of concern" because of their susceptibility to genetic erosion and population decline (in-situ) unless meta-population management principles are applied.

\section{Aquatic environment}

There is a need to further develop our understanding of the temporal duration of effects of tree removal on water runoff in watersheds. Many studies are based on results from only a few years (Carignan et al. 2000). It is thus important to collect information over longer time periods and from different regions (e.g., claybelt, and hilly or mountainous regions with different parent materials) (Borman and Likens 1979).

\section{Soils}

More research is needed on the long-term changes in nutrient reserves and fertility of poor sites, and on the effects of harvesting on productivity and temporal responses of nutrient cycles. We thus need to:

1) Better understand the long-term effects of harvesting (including harvesting at different intensities and salvage logging), of site preparation and of fire suppression on the quality of soil organic matter, on organic layers (such as organic matter accumulation or paludification) and on mineral soil, as well as the linkages of these effects to tree health and productivity;

2) Understand the impact of intensive forest management (ligniculture) on the soil nutrient capital;

3) Evaluate the links between soil chemical composition and water quality, and then apply this knowledge at different spatio-temporal scales to make sustainable management decisions with respect to forestry operations.

Finally, it is important to consider links with other criteria and indicators such as long-term and large-scale biogeochemical cycles (i.e., CCFM Criterion 4), forest regeneration and stand dynamics (i.e., part of CCFM Criterion 2), and socio-economic values associated with the forest (i.e., CCFM Criteria 5 and 6). Some indicators may link together (i.e., be complementary) and lead toward similar solutions, whereas others may suggest opposite courses of action. Understanding these interactions over large temporal and spatial scales will be a key element to achieving SFM.

Foresters and researchers also need reference points in natural areas against which they can compare and evaluate the success of forestry operations. It has been suggested that conditions following natural disturbances could be used as the basis of such a system of reference. This implies that condi- 
tions are dynamic and that we should compare the relationship between the vegetation response after fire to a forestry operation through time (Burton et al. 2003). Therefore, different species will be adapted to or associated with different conditions found at different moments in time. A static approach, such as the use of regulations, will not correspond to the maintenance of dynamic conditions.

Multiple flexible standards should be developed to reflect all of the ecological conditions found in each of the provinces. Finally, it is imperative that effective monitoring programs be put in place and that the state of these multiple forest resources be reported in a clear and transparent manner.

\section{Conclusion}

Forest management is complex. However, recent decades have seen an improvement in forest management linked to an increase in scientific knowledge (Erdle 1998) (Table 1). The RNI in Quebec, the Ground Rules in Alberta and the Forest Operations and Silviculture Manual in Ontario are tools that are complementary to other legal measures and regulations that are useful in attaining many objectives of certification programs and of sustainable forest management.

It should be remembered that the goal of the evaluated regulations and manuals was not to ensure sustainable management of all resources in the forest, but rather to control and limit certain potential problems. In Quebec, for example, the identified problems are those that are effectively controlled using a regulatory approach. However, an approach by objectives could be a more effective means of meeting SFM than a regulatory approach, as long as good indicators and measurable results are clearly defined. Blanket approaches that apply one rule across large territories risk leading to inefficient strategies. Creating incentives for forest companies to go beyond provincial rules (or guidelines) will be a plus for sustainable forest management.

\section{Acknowledgements}

We would like to thank the generous contribution of members of the staff at the MRNQ who took the time to read and comment on this manuscript as well as a DRF-MRNQ researcher who contributed many ideas and suggestions. It is also important to recognise the input of personnel from the MNR in Ontario as well as staff at the Alberta Sustainable Resource Development for their aid with the regulations in those provinces. We would also like to thank all who made us reflect on this subject and who made comments on the text. Particularly, we note our appreciation to Christian Messier, Alain Leduc, Alison Munson, Francine Tremblay, members of forest companies as well as many others. We would also like to thank Myriam Jourdain for her help with this article. Finally, we would like to recognize the financial and technical support we received from the NSERC-UQAM-UQAT Chair in Sustainable Forest Management, the Sustainable Forest Management Network and the FQRNT and industrial forest partners.

\section{References}

Alberta Environmental Protection, 1994. The Timber Harvest Planning and Operating Ground Rules. 57 p.

Borman, FH. and G.F. Likens. 1979. Pattern and process in a forested ecosystem. Springer-Verlag, New York. 253 p.
Bourgeois, L., D.D. Kneeshaw and G. Boisseau, G. 2006. Les routes forestières : le Québec doit considérer les impacts. Vertigo. 6(2): 1-9. Brais, S. 2001. Persistence of soil compaction and effects on seedling growth in northwestern Quebec. Soil Sci. Soc. Am. J. 65: 1263-1271. Brais, S. and C. Camiré. 1998. Soil compaction in the clay belt region of northwestern Quebec (Canada). Can. J. Soil Sci. 78: 197-206.

Burton, P.J., C. Messier, D.W. Smith and W.L. Adamowicz. 2003. Towards Sustainable Management of the Boreal Forest. NRC Research Press, Ottawa, ON. 1039 p.

Carignan, R., D. Planas and P. Magnan. 2000. Attenuating forest harvesting impacts on lakes of the Haute-Mauricie region. In D.D. Kneeshaw et al. Towards Ecological Forestry: A proposal for Indicators of SFM inspired by Natural Disturbances. pp. 21-28. Sustainable Forest Management Network - A Network of Centres of Excellence. 58 p. Available at http://www.sfmnetwork.ca/english/ pubs/PDF/SP_kneeshaw_en.pdf

Canadian Council of Forest Ministers. 2003. Defining Sustainable Forestry in Canada: Criteria and Indicators. Canadian Council of Forest Ministers [online]. Available at http://www.ccfm.org/ 2000pdf/CI_Booklet_e.pdf. [cited February 2004].

Erdle, T. 1998. Progress towards sustainable forest management: Insight from the New Brunswick experience. For. Chron. 74(3): 378-384.

Franklin, J.F. 1993. Preserving biodiversity: species, ecosystems, or landscapes? Ecol. Appl. 3: 202-205.

Hannah, K.C. and J.S. Hoyt. 2004. Northern Hawk Owl and recent burns: does burn age matter? Condor 106: 420-423.

Hanski, I. 2000. Extinction debt and species credit in boreal forests: modelling the consequences of different approaches to biodiversity conservation. Ann. Zool. Fennici 37: 271-280.

Hunter, M.L., Jr., G.L. Jacobson Jr. and T. Webb III. 1988. Paleoecology and the coarse-filter approach to maintaining biological diversity. Conservation Biology 2(4): 375-385.

Imbeau, L. and A. Desrochers. 2002. Foraging ecology and use of drumming trees by three-toed woodpeckers. J. Wildl. Manage 66: 222-231.

Jetté, J.-P., A. Robitaille, J. Pâquet and G. Parent. 1998. Guide des saines pratiques forestières dans les pentes du Québec. Ministère des Ressources Naturelles. MRNQ, Québec. 60 p.

Joyce, D., P. Nitschke and A. Mosseler. 2001. Genetic Resource Management. pp. 141-154 In R.G. Wagner and S.J. Colombo (eds.). Regenerating the Canadian Forest - Principles and Practice for Ontario. Fitzhenry and Whiteside Ltd., Markham, ON. 650 p.

Kneeshaw, D.D. and L. Bourgeois. 2003. Evaluation of the links between forest operations laws and the sustainable forest management indicators in Alberta, Ontario \& Quebec. Sustainable Forest Management Network. 7 p. Available at http://web2.uqat.ca/cafd/ publication/pub_pdf/AOQ.pdf

Kneeshaw, D.D., L. Bourgeois, N. Bélanger, S. Brais, L. Imbeau and S. Yamasaki. 2003. Evaluation of the links between the RNI (Payment on the Standards of Intervention in the Forests of the field of State) and the sustainable forest management indicators. Chaire en Aménagement Forestier Durable et Groupe de Recherche en Écologie Forestière interuniversitaire (GREFi). 97 p.

Kneeshaw, D.D., A. Leduc, C. Messier, P. Drapeau, D. Paré, S. Gauthier, R. Carignan, R, Doucet and L. Bouthillier. 2000a. Developing biophysical indicators of sustainable forest management at an operational scale. For. Chron. 76: 482-493.

Kneeshaw, D.D., C. Messier, J.-P. Ricard, A. Leduc, P. Drapeau, D. Paré, R. Carignan, S. Gauthier, R. Doucet and D. Greene. 2000b. Vers une foresterie écologique : une proposition pour indicateurs de GDF qui s'inspirent des perturbations naturelles. Brochure de transfert technologique. Réseau sur la Gestion Durable des Forêts - Un réseau de centres d'excellence. 58 p. Available at http://www.sfmnetwork.ca/english/pubs/PDF/SP_kneeshaw_fr.pdf

L'Écuyer, H. and J.-P. Jetté. 1998. Indicateurs des perturbations physiques du sol. Volet réseau routier et son environnement immé- 
diat. Note technique, Direction de l'environnement forestier. MRNQ, Québec. 4 p. Available at http://www.mrnf.gouv.qc.ca/publications/forets/connaissances/RN983077.pdf

Lindenmayer, D.B., D.R. Foster, J.F. Franklin, M.L. Hunter, R.F. Noss, F.A. Schmiegelow and D. Perry. 2004. Salvage harvesting policies after natural disturbance. Science 303(5662): 1303.

McComb, W. and D. Lindenmayer. 1999. Dying, dead, and down trees. In M.L. Hunter (ed.). Maintaining biodiversity in forest ecosystems. pp. 335-372. Cambridge University Press.

Ministère du Conseil Exécutif du Québec. 2001. La réglementation par objectifs : proposition du groupe de travail Justice-Secrétariat à l'allégement réglementaire. Conseil exécutif. $21 \mathrm{p}$.

Ministère de l'Environnement. 2002. Loi sur la qualité de l'environnement. Chapitre Q-2.

Ministère des Ressources Naturelles du Québec. 1997. Guide - L'aménagement des ponts et des ponceaux dans le milieu forestier. $147 \mathrm{p}$. Ministère des Ressources Naturelles du Québec. 2001. Guide de référence de l'aménagement durable des forêts. Direction des programmes forestiers.

Ministère des Ressources Naturelles du Québec. 2002a. Loi sur les forêts. (L.R.Q., c. F-4.1).

Ministère des Ressources Naturelles du Québec. 2002b. Règlement sur les normes d'intervention dans les Forêts du domaine de l'État. Loi sur les forêts. (L.R.Q., c. F-4.1, a. 171).

Molloy, R., R. Torresan and N. Boissonnault. 2001. Saines pratiques : Voirie forestière et installation de ponceaux. Direction régionale Gaspésie-Iles-de-la-Madeleine du Ministère des Ressources Naturelles. 27 p.

Nappi A, P. Drapeau, J.-P. L. Savard. 2004. Salvage logging after wildfire in the boreal forest: Is it becoming a hot issue for wildlife? For. Chron. 80(1): 67-74.
Ontario Ministry of Natural Resources. 1984a. Habitat management guidelines for Ontario's forests nesting accipiters, buteos and eagles. $23 \mathrm{p}$.

Ontario Ministry of Natural Resources. 1984b. Habitat management guidelines for cavity-nesting birds in Ontario. $40 \mathrm{p}$.

Ontario Ministry of Natural Resources. 1984c. Habitat management guidelines for bats in Ontario. $42 \mathrm{p}$.

Ontario Ministry of Natural Resources. 1995. Forest Operations and Silviculture Manual. Prepared under the authority of the Crown Forest Sustainability Act. 400 p.

Ontario Ministry of Natural Resources. 1998. Code of Practice For Timber Management Operations In Riparian Areas. Amended in 1998. 9 p.

Paré, D., P. Rochon and S. Brais S. 2002. Assessing the geochemical balance of managed boreal forests. Ecol. Indic 28: 1-19.

Plamondon, A. P. 1993. Influence des coupes forestière sur le régime d'écoulement de l'eau et sa qualité : revue de la littérature. Dir. Env. MRNQ. C-47. 179 p.

Schreiber, A., N. Lafontaine and J.-P. Jetté, J.P. 1999. L'orniérage après coupe dans les milieux forestiers humides. Résultats d'un suivi effectué au Québec en 1998. Note technique, Direction de l'environnement forestier. MRNQ, Québec. 4 p.

Similä M., J. Kouki and P. Martikainen. 2003. Saproxylic beetles in managed and seminatural Scots pine forests: quality of dead wood matters. For. Ecol. Manage. 174(1-3): 365-381.

Tilman, D., R.M. May, C.L. Lehman and M.A. Nowak. 1994. Habitat destruction and the extinction debt. Nature 371: 65-66. 